\title{
Article \\ New Bithiophene Extended IDIC-Based Non-Fullerene Acceptors and Organic Photovoltaics Thereof
}

\author{
Yeong Heon Jeong ${ }^{1,+}$, Jae Min Jeon ${ }^{2,+}$, Jun Young Kim ${ }^{2, *}$ and Yun-Hi Kim ${ }^{1, *}$ \\ 1 Department of Chemistry and RINS, Gyeongsang National University, Jinju 660-701, Korea; \\ dudgjs02@naver.com \\ 2 Department of Semiconductor Engineering, Gyeongsang National University, Jinju 660-701, Korea; \\ jmjeon95@gnu.ac.kr \\ * Correspondence: kimjy86@gnu.ac.kr (J.Y.K.); ykim@gnu.ac.kr (Y.-H.K.); Tel.: +82-55-772-1732 (J.Y.K.); \\ +82-55-772-1491 (Y.-H.K.) \\ + These authors contributed equally to this work.
}

Citation: Jeong, Y.H.; Jeon, J.M.; Kim, J.Y.; Kim, Y.-H. New Bithiophene Extended IDIC-Based Non-Fullerene Acceptors and Organic Photovoltaics Thereof. Molecules 2022, 27, 1113. https:// doi.org/10.3390/molecules27031113

Academic Editors: Minas M.

Stylianakis and Ashok Kakkar

Received: 23 December 2021

Accepted: 2 February 2022

Published: 7 February 2022

Publisher's Note: MDPI stays neutral with regard to jurisdictional claims in published maps and institutional affiliations.

Copyright: (C) 2022 by the authors. Licensee MDPI, Basel, Switzerland. This article is an open access article distributed under the terms and conditions of the Creative Commons Attribution (CC BY) license (https:// creativecommons.org/licenses/by/ $4.0 /)$

\begin{abstract}
We developed new bithiophene extended electron acceptors based on $m$-alkoxythenylsubstituted IDIC with three different end groups, named as IDT-BT-IC, IDT-BT-IC4F, and IDT-BT$\mathrm{IC} 4 \mathrm{Cl}$, respectively. The ultraviolet absorption maximum was redshifted and the bandgap was decreased as the strong electron accepting ability of the end group increased. A differential scanning calorimetry thermogram analysis revealed that all the new acceptors have a crystalline character. Using these acceptors and a bulk heterojunction structure using PBDB-T, inverted organic photovoltaic (OPV) devices were fabricated, and their performance was analyzed. Due to the red shift of the electron acceptors, the OPV active layer particularly, which was derived from IDT-BT-IC4F, exhibited increased absorption at long wavelengths over $800 \mathrm{~nm}$. The OPV prepared using IDT-BT-IC exhibited a short-circuit current density $\left(\mathrm{J}_{\mathrm{sc}}\right)$ of $2.30 \mathrm{~mA} / \mathrm{cm}^{2}$, an open-circuit voltage $\left(\mathrm{V}_{\mathrm{oc}}\right)$ of $0.95 \mathrm{~V}$, a fill factor (FF) of $45 \%$, and a photocurrent efficiency (PCE) of $1.00 \%$. Using IDT-BT-IC4F, the corresponding OPV device showed $\mathrm{J}_{\mathrm{sc}}=8.31 \mathrm{~mA} / \mathrm{cm}^{2}, \mathrm{~V}_{\mathrm{oc}}=0.86 \mathrm{~V}, \mathrm{FF}=47 \%$, and $\mathrm{PCE}=3.37 \%$. The IDT-BT-IC4Cl-derived OPV had $\mathrm{J}_{\mathrm{sc}}=3.00 \mathrm{~mA} / \mathrm{cm}^{2}, \mathrm{~V}_{\mathrm{oc}}=0.89 \mathrm{~V}, \mathrm{FF}=29 \%$, and PCE $=0.76 \%$. When IDT-BT-IC4F was used as the electron acceptor, the highest $\mathrm{J}_{\mathrm{Sc}}$ and PCE values were achieved. The results show that the low average roughness $(0.263 \mathrm{~nm})$ of the active layer improves the extraction of electrons.
\end{abstract}

Keywords: non-fullerene acceptors; IDIC; organic photovoltaic

\section{Introduction}

The development of photovoltaic technologies has advanced rapidly with the increasing demand for renewable energy sources to solve environmental pollution. Among the available solar cell technologies, organic photovoltaics (OPVs) stand out due to their easy processability, low cost, light weight, and flexibility [1-6].

In general, OPVs are prepared by constructing a bulk heterojunction (BHJ), which is an active layer comprising a blend of an electron donor (D) and electron acceptor (A), via a solution process, which provides large-area OPVs using the roll-to-roll process [4-8].

In contrast with the intensive research that has been conducted to obtain donor materials, the development of acceptor materials has lagged behind because fullerene derivatives are commonly used as electron acceptors. Fullerene derivatives are characterized by a fully conjugated $\mathrm{sp}^{2}$-hybridized structure, which provides excellent electron transport and acceptor capacity and promotes electron delocalization. Despite having these desirable properties, the three-dimensional structure of fullerenes limits their practical application. Thus, these compounds suffer from weak light absorption, difficulty in energy state control and backbone control, and photochemical and morphological instability [1-3,9]. Consequently, the development of non-fullerene acceptors (NFAs) has been actively pursued. 
Representative non-fullerene acceptors are BTP-eC9 [10], BTP-4F-PC6 [11], Y6 [12], and IDIC [13]. With high absorption coefficient due to their planar two-dimensional structure, NFAs can be easily tuned to achieve energy compatibility and optical complementarity with various donor polymers, affording a wide solar spectrum coverage. In addition, their easy synthesis and purification processes can reduce the production cost compared with fullerenes [1-3,6,14-18]. NFAs based on indaceno[1,2-b:5,6-b'] dithiophene (IDT) with electron-rich ring-fused linear ladder structures [19], such as IDIC or ITIC derivatives, are ring-fused materials having a push-pull A-D-A structure [20,21]. These A-D-A-type IDIC or ITIC derivatives have a high power conversion efficiency of around $14 \%$.

In this work, we designed A-D'-D-D'-A-structured IDIC derivatives with extended bithiophenes to increase the LUMO energy level for high open-circuit voltage $\left(\mathrm{V}_{\mathrm{oc}}\right)$. The physical properties of bithiophene extended ITIC derivatives were also compared with those of IDIC derivatives. Moreover, the performance of OPV devices fabricated using these derivatives was studied.

\section{Results and Discussion}

\subsection{NFA Characteristics}

Scheme 1 depicts the synthesis of the materials, which involved various organic reactions such as formylation, Stille coupling reaction, nucleophilic substitution, and Knoevenagel condensation. The structures of intermediate materials and the final compounds were characterized by ${ }^{1} \mathrm{H}$ nuclear magnetic resonance (NMR), ${ }^{13} \mathrm{C} \mathrm{NMR}$, and mass spectroscopies. (Supplementary Material; Figures S1-S25). The details of their synthesis and characterization are described in the Supporting Information. As a donor material, poly[(2,6-(4,8-bis(5-(2-ethylhexyl)thiophene-2-yl)-benzo[1,2-b:4,5-b']dithiophene))-alt(5,5-(1', $3^{\prime}$-di-2-thienyl-5', $7^{\prime}$-bis(2-ethylhexyl) benzo[1 $\left.1^{\prime}, 2^{\prime}-\mathrm{c}: 4^{\prime}, 5^{\prime}-\mathrm{c}^{\prime}\right]$ dithiophene-4,8-dionz) (PBDB-T) was used.
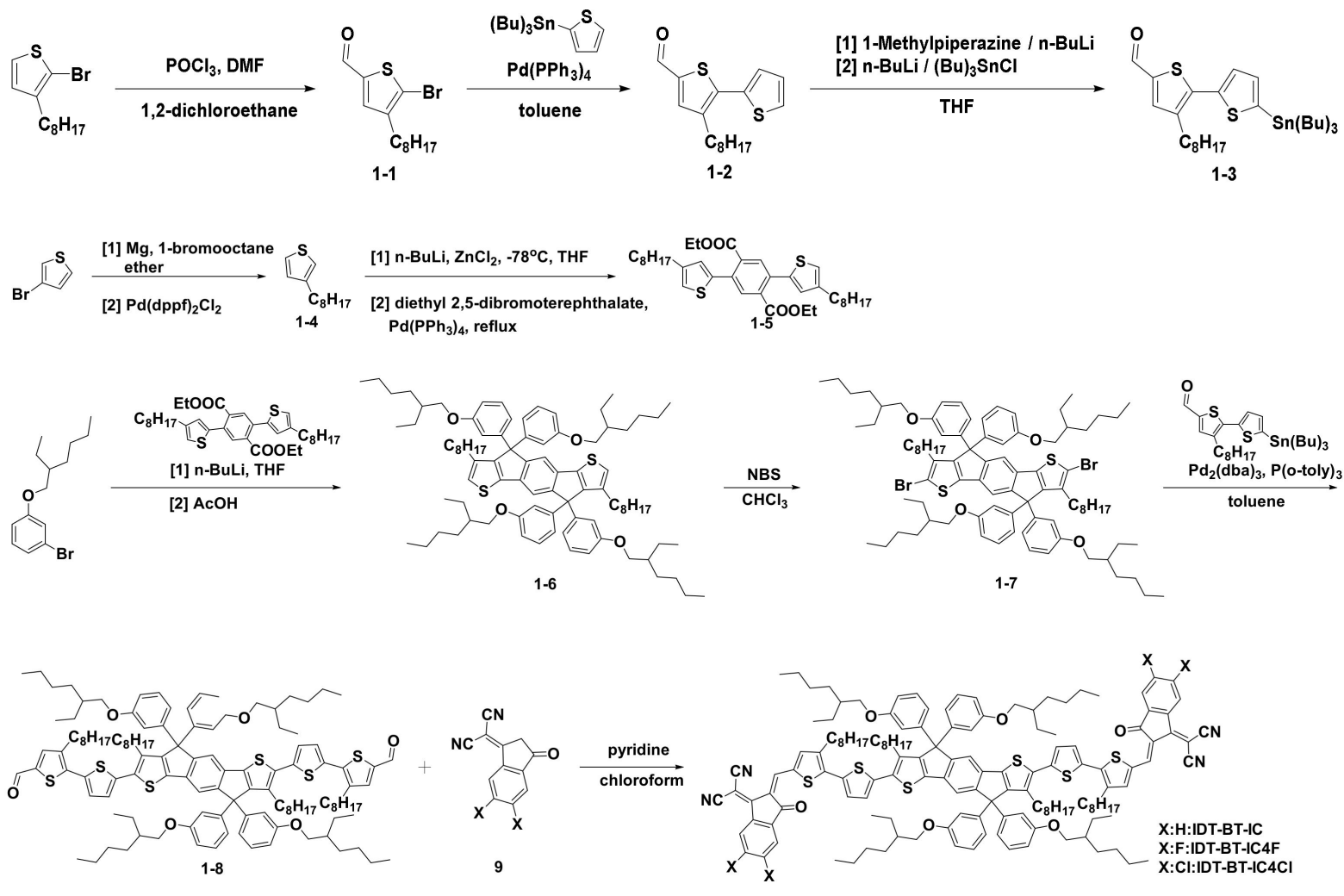

Scheme 1. Synthesis of IDT-BT-IC, IDT-BT-IC4F, and IDT-BT-IC4Cl. 
The optical properties of the new NFAs were investigated by ultraviolet-visible (UVvis) spectroscopy in chloroform solution at a certain concentration $\left(1 \times 10^{-5} \mathrm{M}\right)$ and in film state (Figure S26). In solution, IDT-BT-IC, IDT-BT-IC4F, and IDT-BT-IC4Cl showed absorption maxima at 682,710 , and $726 \mathrm{~nm}$, respectively, which were redshifted with increasing the electronegativity of the end group. Thus, the UV absorption maximum of IDT-BT-IC was redshifted by almost $50 \mathrm{~nm}$ compared with ITIC-OEh without the bithiophene unit [22]. This suggests that the introduction of the bithiophene unit extended the conjugation in the molecule. A redshift of 50-70 nm was observed for all the compounds in the film state. Meanwhile, the optical bandgap was gradually decreased as the electronegativity of the end group increased. The HOMO and LUMO energies of the new NFAs were determined by cyclic voltammetry and optical bandgap measurements (Figure S27). Similar values of $-5.25,-5.25$, and $-5.26 \mathrm{eV}$ were obtained for the HOMO levels of IDT-BT-IC, IDTBT-IC4F, and IDT-BT-IC4Cl, respectively, whereas the LUMO energy level of IDT-BT-IC, IDT-BT-IC4F, and IDT-BT-IC4Cl was $-3.82,-3.86$, and $-3.88 \mathrm{eV}$, respectively. The optical and electrochemical properties are summarized in Table 1. The thermal stability of IDT-BT-IC, IDT-BT-IC4F, and IDT-BT-IC4Cl was examined by thermogravimetry analysis and differential scanning calorimetry. For all NFAs, the decomposition temperature at 5\% weight loss was observed at above $335^{\circ} \mathrm{C}$. The ID-BT-based new NFAs showed a crystalline nature with a melting transition at $267-276{ }^{\circ} \mathrm{C}$ and a crystallization transition at $294-229^{\circ} \mathrm{C}$. (Figure S28).

Table 1. Photovoltaic parameters of organic photovoltaic using different NFAs.

\begin{tabular}{|c|c|c|c|c|c|c|c|}
\hline NFAs & $\mathrm{J}_{\mathrm{sc}}\left(\mathrm{mA} / \mathrm{cm}^{2}\right)$ & $\mathrm{V}_{\text {oc }}(\mathrm{V})$ & FF (\%) & PCE (\%) & $R_{\mathrm{sh}}\left(\Omega \mathrm{cm}^{2}\right)$ & $R_{s}\left(\Omega \mathrm{cm}^{2}\right)$ & $R_{\text {s dark }}\left(\Omega \mathrm{cm}^{2}\right)$ \\
\hline IDT-BT-IC & $2.30 \pm 0.31$ & $0.95 \pm 0.03$ & $45 \pm 2$ & $1.00 \pm 0.20$ & $830 \pm 24$ & $56 \pm 8$ & $1.35 \pm 0.20$ \\
\hline IDT-BT-IC4F & $8.31 \pm 0.51$ & $0.86 \pm 0.02$ & $47 \pm 3$ & $3.37 \pm 0.51$ & $337 \pm 15$ & $18 \pm 2$ & $1.31 \pm 0.15$ \\
\hline IDT-BT-IC4Cl & $3.00 \pm 0.52$ & $0.89 \pm 0.03$ & $29 \pm 2$ & $0.76 \pm 0.24$ & $361 \pm 10$ & $139 \pm 9$ & $40.27 \pm 2.23$ \\
\hline
\end{tabular}

\subsection{OPV Characteristics}

Figure 1 shows the characteristics of a series of OPV devices fabricated using IDT-BTIC, IDT-BT-IC4F, and IDT-BT-IC4Cl by spin coating. The absorption spectra of the thin films depicted in Figure 1a shows that all NFAs produced a maximum absorption peak at about $620 \mathrm{~nm}$ with a shoulder from ca. 700 to $800 \mathrm{~nm}$ and a less intense peak at about $580 \mathrm{~nm}$. These peaks are weaker in the case of IDT-BT-IC4F. Figure $1 \mathrm{~b}$ shows the changes in the current density with voltage under light irradiation at $100 \mathrm{~mW} / \mathrm{cm}^{2}$. Detailed parameter values of Figure $1 \mathrm{~b}$ are shown in Table 1. IDT-BT-IC afforded the lowest short-circuit current density $\left(\mathrm{J}_{\mathrm{sc}}\right)$ of $2.30 \mathrm{~mA} / \mathrm{cm}^{2}$ among the NFAs. The corresponding values for IDT-BT-IC4Cl and IDT-BT-IC4F were 3.00 and $8.31 \mathrm{~mA} / \mathrm{cm}^{2}$, respectively, which indicates that the current density increased when adding a halogen element.

The $\mathrm{V}_{\mathrm{Oc}}$ of IDT-BT-IC without halogen elements was $0.95 \mathrm{~V}$, which was $0.06 \sim 0.09 \mathrm{~V}$ higher than that of the other two NFAs $(0.86 \mathrm{~V}$ for IDT-BT-IC4F and $0.89 \mathrm{~V}$ for IDT-BT-IC4Cl). When designing the structure, high $\mathrm{V}_{\mathrm{oc}}$ was expected due to the improvement of the LUMO level, but it seems that the maximum $\mathrm{V}_{\mathrm{oc}}$ did not come out due to changes in other factors. $\mathrm{V}_{\text {loss }}$ is one of the most important factors limiting the PCE of the OPVs. In particular, the contribution from non-radiative $\mathrm{V}_{\text {loss }}$ should be reduced, which is mainly affected by the energetic interactions between the donor polymer and acceptors at the interfaces. Thus, the interfacial and morphological properties (i.e., domain size/purity, aggregation, and molecular orientation) of the $\mathrm{BHJ}$ blend should be optimized to decrease the non-radiative $\mathrm{V}_{\text {loss }}$ [23]. The fill factor (FF), which is the ratio of the actual maximum obtainable power to the product of $\mathrm{I}_{\mathrm{SC}}$ and $\mathrm{V}_{\mathrm{Oc}}$, is greatly affected by internal resistance, with large shunt resistance $\left(R_{s h}\right)$ and small series resistance $\left(R_{s}\right)$ improving the FF $[24,25]$. The $R_{s}$ and $R_{s h}$ can be obtained from the $\mathrm{J}-\mathrm{V}$ graph under light irradiation at $100 \mathrm{~mW} / \mathrm{cm}^{2} . \mathrm{R}_{\mathrm{s}}$ and $\mathrm{R}_{\mathrm{sh}}$ are the inverses of the slopes at $\mathrm{V}_{\mathrm{OC}}$ and $\mathrm{J}_{\mathrm{Sc}}$. These conditions were not satisfied by IDT-BT-IC and IDT-BT-IC4F; IDT-BT-IC had high $R_{\mathrm{s}}$ and $R_{\mathrm{sh}}$ values of 56 and $830 \Omega \mathrm{cm}^{2}$, respectively, and 
IDT-BT-IC4F showed low $R_{\text {sh }}$ and $R_{s}$ values of 337 and $18 \Omega \mathrm{cm}^{2}$, respectively, affording similar FF values of $45 \%$ and $47 \%$. Therefore, satisfying only one of the conditions (high $\mathrm{R}_{\mathrm{sh}}$ or low $\mathrm{R}_{\mathrm{s}}$ ) did not give a high FF [26]. Meanwhile, IDT-BT-IC4Cl showed a lower FF of about $29 \%$ due to its low $R_{\mathrm{sh}}\left(361 \Omega \mathrm{cm}^{2}\right)$ and high $\mathrm{R}_{\mathrm{s}}\left(139 \Omega \mathrm{cm}^{2}\right)$. As shown in Table 1, IDT-BT-IC4Cl had the lowest photocurrent efficiency (PCE) of $0.76 \%$ due to its low current density $\left(3.00 \mathrm{~mA} / \mathrm{cm}^{2}\right)$ and FF $(29 \%)$. Furthermore, IDT-BT-IC showed a PCE of $1.00 \%$ owing to its low current density $\left(2.30 \mathrm{~mA} / \mathrm{cm}^{2}\right)$ and high FF $(45 \%)$, and IDT-BT-IC4F showed the highest PCE of $3.37 \%$ due to its high current density $\left(8.31 \mathrm{~mA} / \mathrm{cm}^{2}\right)$ and FF $(47 \%)$. Figure $1 \mathrm{c}$ shows the J-V plot measured in the dark state, which is a semi-log graph in which the $y$ axis is expressed on a log scale to observe the characteristics of the current density. In the reverse bias voltage region below $0 \mathrm{~V}$, IDT-BT-IC exhibited lower current density than the other two devices, which is indicative of lower leakage current. A low leakage current is closely related to $R_{s h}$. Thus, the lower leakage current of IDT-BT-IC can be attributed to its higher $\mathrm{R}_{\mathrm{sh}}$ compared with that of IDT-BT-IC4F and IDT-BT-IC4Cl. We extracted the series resistance in the $4-5 \mathrm{~V}$ range of dark $\mathrm{I}-\mathrm{V}$ in Figure $1 \mathrm{c}$, and expressed it as $R_{s \text { dark }}$. The value of $R_{s}$ dark is $1.35,1.31,40.27 \Omega \mathrm{cm}^{2}$ for IDT-BT-IC, IDT-BT-IC4F and IDT-BT-IC4Cl respectively. IDT-BT-IC4Cl has high series resistance at dark current, It shows a similar trend to $R_{s}$ in the J-V graph under light irradiation at $100 \mathrm{~mW} / \mathrm{cm}^{2}$. Figure $1 \mathrm{~d}$ shows the changes in the external quantum efficiency (EQE) with the wavelength in the range from 350 to $800 \mathrm{~nm}$. For all the wavelength range, IDT-BT-IC4F showed the highest EQE. EQE represents the generation of an electron-hole pair upon absorption of light in the active layer, followed by charge separation and transfer to both electrodes, generating a current. In other words, light absorption is crucial, but it is also essential to allow the generation of electron-hole pairs as an electric current without recombination. Therefore the absorption of the photoactive layer and the EQE of the OPV device do not entirely match. This is because the OPV device is not only the photoactive layer but also may be caused by the material of the charge extraction and the roughness of the interface layer so that the absorption and EQE graphs do not match [27].

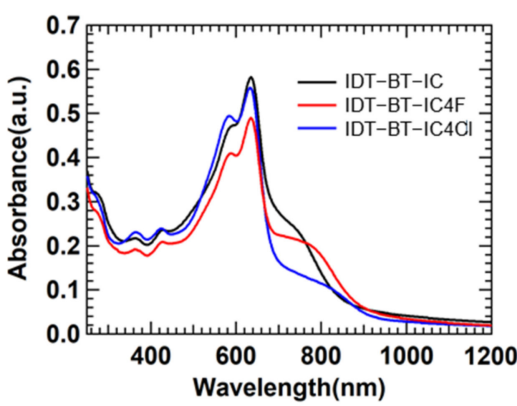

(a)

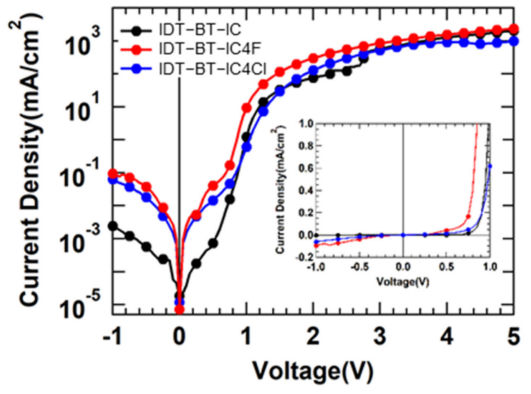

(c)

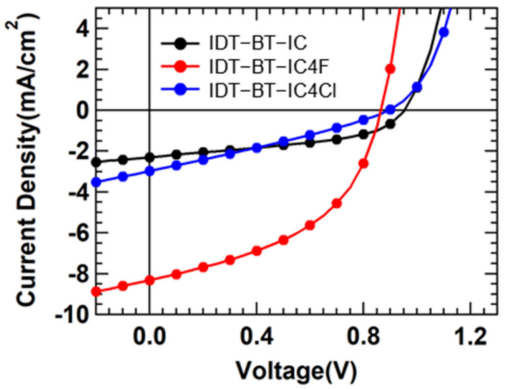

(b)

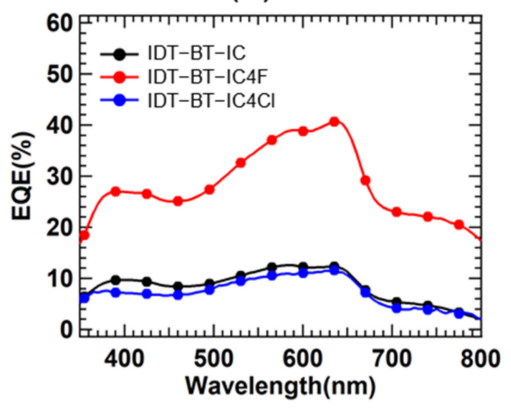

(d)

Figure 1. Performance of organic photovoltaic devices fabricated with different non-fullerene acceptors (NFAs): (a) Absorbance spectra of PBDB-T:NFA, (b) $J-V$ plot at AM 1.5G $\left(100 \mathrm{~mW} / \mathrm{cm}^{2}\right)$, (c) dark $J-V$ plot(inset: dark $J-V$ linearly plot), (d) external quantum efficiency (EQE) spectra. 
As shown in Figure 1a, IDT-BT-IC4F had the lowest absorption rate; however, its EQE value was significantly higher than that of the other two devices. This indicates that charge recombination is prevented after electrons and holes are separated, which means that the generation of current is enhanced in IDT-BT-IC4F.

Figure 2 shows atomic force microscopy (AFM) images of various photoactive layers. The size of the AFM image was $5 \mu \mathrm{m} \times 5 \mu \mathrm{m}$. According to these images, the average roughness $\left(\mathrm{R}_{\mathrm{a}}\right)$ of the surface was $1.649 \mathrm{~nm}$ for IDT-BT-IC, $0.263 \mathrm{~nm}$ for IDT-BT-IC4F, and $0.430 \mathrm{~nm}$ for IDT-BT-IC4Cl. The high $\mathrm{R}_{\mathrm{a}}$ of IDT-BT-IC limits the movement of electronhole pairs, resulting in the lowest current density value of $2.30 \mathrm{~mA} / \mathrm{cm}^{2}$. Similarly, its leakage current was low because it prevents the movement of charges by the electric field at reverse bias voltage. In contrast, the halogen-containing photoactive layers exhibited low surface roughness. Among these two devices, IDT-BT-IC4Cl showed many pinholes and white spots because the arrangement between particles was not dense, which results in a low current density of $3.00 \mathrm{~mA} / \mathrm{cm}^{2}$. IDT-BT-IC4F had few pinholes or white spots, which provides a flat surface for a smooth charge transfer, thereby improving the interface performance with $\mathrm{MoO}_{3}$ to achieve the highest current density of $8.31 \mathrm{~mA} / \mathrm{cm}^{2}$. As a result, although the absorption of PBDB-T:IDT-BT-IC4F is the lowest at $600 \mathrm{~nm}$, the reason why the EQE is the highest is because the morphological properties are greatly improved compared to other PBDB-T:NFAs.

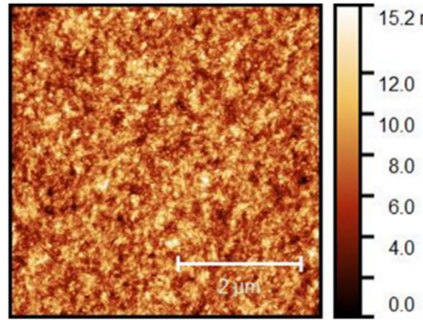

(a)

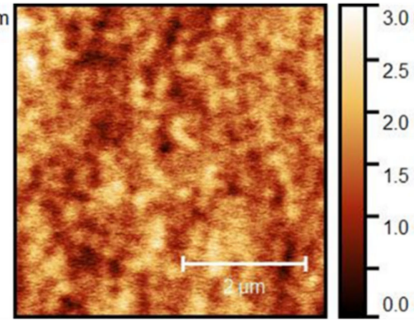

(b)

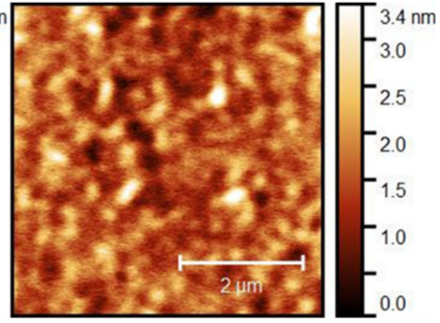

(c)

Figure 2. Atomic force microscopy images of (a) IDT-BT-IC, (b) IDT-BT-IC4F, and (c) IDT-BT-IC4Cl films with a scan size of $5 \mu \mathrm{m} \times 5 \mu \mathrm{m}$.

\section{Materials and Methods}

\subsection{Synthesis of the NFAs}

3.1.1. Synthesis of 4,4,9,9-Tetrakis(3-((2-ethylhexyl)oxy)phenyl)-3,8-dioctyl-4,9-dihydro-sindaceno[1,2-b:5,6-b']dithiophene (6)

In a three-neck round bottom flask (DAIHAN Scientific Co, Ltd., Wonju, Korea), to a stirring solution of 1-bromo-3-((2-ethylhexyl)oxy)benzene $(9.08 \mathrm{~g}, 31.85 \mathrm{mmol})$ in dried THF $(70 \mathrm{~mL})$ was added dropwise a $2.5 \mathrm{M}$ solution of $n$-BuLi in $n$-hexane $(12.74 \mathrm{~mL})$ under $\mathrm{N}_{2}$ condition at $-78^{\circ} \mathrm{C}$ (Merk KGaA, Darmstadt, Germany). After $1.5 \mathrm{~h}$ at this temperature, the solution temperature was raised slowly to $-65^{\circ} \mathrm{C}$. Then, a solution of compound 5 $(75 \mathrm{~mL}, 6.37 \mathrm{mmol})$ in THF was added dropwise into the solution at $-65^{\circ} \mathrm{C}$. After slowly warming up to ambient temperature, the mixture was kept for $8 \mathrm{~h}$, followed by addition of water, and the mixture was extracted with ethyl acetate and dried over $\mathrm{MgSO}_{4}$. After evaporating the solvent, the hydroxy intermediate was dissolved with glacial acetic acid $(300 \mathrm{~mL})$, and the solution of the intermediate was then refluxed for $3 \mathrm{~h}$ under $\mathrm{N}_{2}$ condition. After cooling to ambient temperature, water was added and the mixture was extracted with dichloromethane, washed with water, dried over $\mathrm{MgSO}_{4}$, and concentrated. The residue was purified by column chromatography (Merk KGaA, Darmstadt, Germany) using methylene chloride: $n$-hexane $(v: v=1: 3)$ as an eluent to obtain the product as a white solid (2.5 g, 30\%). ${ }^{1} \mathrm{H}$ NMR (300 MHz, $\left.\mathrm{CD}_{2} \mathrm{Cl}_{2}, \delta\right): 7.41(\mathrm{~s}, 2 \mathrm{H}), 7.15-7.20(\mathrm{t}, 4 \mathrm{H}), 6.93$ (s, $2 \mathrm{H}), 6.88-6.90(\mathrm{t}, 4 \mathrm{H}), 6.79-6.83(\mathrm{q}, 8 \mathrm{H}), 3.78-3.80(\mathrm{~d}, J=5.82 \mathrm{~Hz}, 8 \mathrm{H}), 2.32-2.36(\mathrm{t}, 4 \mathrm{H})$, 1.65-1.73 (m, 4H), 1.18-1.54 (m, 56H), 0.89-0.94 (m, 30H). $\left.{ }^{13} \mathrm{C} \mathrm{NMR} \mathrm{(500} \mathrm{MHz,} \mathrm{CDCl}_{3}, \delta\right)$ : $159.08,155.46,153.34,146.87,145.04,144.06,142.88,141.83,139.16,138.33,136.39,135.52$, 
$128.93,121.92,121.10,120.86,115.95,115.68,112.51,70.47,63.58,39.32,33.41,31.90,30.48$, 29.46, 29.37, 29.28, 29.21, 29.05, 28.93, 23.79, 23.05, 22.68, 14.09, 11.07. HR-MS (FAB) $\mathrm{m} / z$ $\mathrm{C}_{88} \mathrm{H}_{123} \mathrm{O}_{4} \mathrm{~S}_{2}$ Calcd: 1306.8785 , Found: 1307.8843 .

3.1.2. Synthesis of 2,7-Dibromo-4,4,9,9-tetrakis(3-((2-ethylhexyl)oxy)phenyl)-3,8-dioctyl-4,9dihydro-s-indaceno[1,2-b:5,6- $\mathrm{b}^{\prime}$ ]dithiophene (7)

To a stirring solution of compound $6(2.21 \mathrm{~g}, 1.69 \mathrm{mmol})$ in dried $\mathrm{CHCl}_{3}(80 \mathrm{~mL}), N$ bromosuccinimide $(0.66 \mathrm{~g}, 3.72 \mathrm{mmol})$ was added three times at ambient temperature, and the mixture was kept for $8 \mathrm{~h}$ in the dark. After pouring water, the mixture was extracted with $\mathrm{CHCl}_{3}$ and dried over $\mathrm{MgSO}_{4}$. After evaporating the solvent, the mixture was purified by column chromatography using silica gel (Merk KGaA, Darmstadt, Germany) and methylene chloride:hexane $(v: v=1: 3)$ as the eluent. Then, the compound was purified by recrystallization from methylene chloride $(1.8 \mathrm{~g}, 72.7 \%) .{ }^{1} \mathrm{H} \mathrm{NMR}\left(300 \mathrm{MHz}, \mathrm{CD}_{2} \mathrm{Cl}_{2}, \delta\right)$ : $7.37(\mathrm{~s}, 2 \mathrm{H}), 7.15-7.21(\mathrm{t}, 4 \mathrm{H}), 6.88(\mathrm{~s}, 4 \mathrm{H}), 6.77-6.83(\mathrm{t}, 8 \mathrm{H}), 3.78-3.80(\mathrm{~d}, 8 \mathrm{H}), 2.31-2.37(\mathrm{~m}$, $4 \mathrm{H}), 1.65-1.73(\mathrm{~m}, 4 \mathrm{H}), 1.10-1.49(\mathrm{~m}, 56 \mathrm{H}), 0.89-0.94(\mathrm{t}, 30 \mathrm{H}) .{ }^{13} \mathrm{C} \mathrm{NMR}\left(500 \mathrm{MHz}, \mathrm{CDCl}_{3}\right.$, $\delta): 159.20,155.06,152.14,143.48,140.45,138.71,135.34,129.14,120.75,115.77,112.57,111.20$, $70.62,64.35,39.33,31.97,30.48,29.75,29.28,29.20,29.11,29.07,28.37,28.27,23.81,23.08$, $22.72,14.13,11.11$. MS (FAB) $m / z$ Calcd: 1462.6995 , Found: 1466.

3.1.3. Synthesis of $5^{\prime}, 5^{\prime \prime \prime}-(4,4,9,9$-Tetrakis(3-((2-ethylhexyl)oxy)phenyl)-3,8-dioctyl-4,9dihydro-s-indaceno[1,2-b:5,6-b'] dithiophene-2,7-diyl)bis(3-octyl-[2,2'-bithiophene]-5carbaldehyde) (8)

Compounds $3(1.76 \mathrm{~g}, 1.2 \mathrm{mmol})$ and 7 (1.79 g, $3.0 \mathrm{mmol})$ were dissolved in dried toluene $(60 \mathrm{~mL})$. After bubbling the solution with $\mathrm{N}_{2}$ gas for $30 \mathrm{~min}, \mathrm{Pd}\left(\mathrm{PPh}_{3}\right)_{4}(0.07 \mathrm{~g}$, $0.06 \mathrm{mmol}$ ) was added and refluxed for $12 \mathrm{~h}$. After the mixture was kept for $8 \mathrm{~h}$, water was poured and the mixture was extracted with $\mathrm{CHCl}_{3}$. After evaporating the solvent, the mixture was purified by silica gel column chromatography using methylene chloride:hexane $(v: v=2: 1)$ as the eluent. Then, the compound was purified by recrystallization from methylene chloride $(1.1 \mathrm{~g}, 48 \%) .{ }^{1} \mathrm{H}$ NMR $\left(300 \mathrm{MHz}, \mathrm{CD}_{2} \mathrm{Cl}_{2}, \delta\right): 9.84(\mathrm{~s}, 2 \mathrm{H}), 7.64(\mathrm{~s}, 2 \mathrm{H}), 7.45$ $(\mathrm{s}, 2 \mathrm{H}), 7.29-7.30(\mathrm{~d}, 2 \mathrm{H}), 7.18-7.24(\mathrm{~m}, 6 \mathrm{H}), 6.97(\mathrm{~s}, 4 \mathrm{H}), 6.82-6.89(\mathrm{t}, 8 \mathrm{H}), 3.80-3.82(\mathrm{~d}$, $J=5.79 \mathrm{~Hz}, 8 \mathrm{H}), 2.83-2.89(\mathrm{t}, 4 \mathrm{H}), 2.52-2.56(\mathrm{~m}, 4 \mathrm{H}), 1.67-1.77(\mathrm{~m}, 8 \mathrm{H}), 1.07-1.53(\mathrm{~m}, 80 \mathrm{H})$, 0.85-0.94 (m, 36H), 0.66-0.71 (m, 4H). ${ }^{13} \mathrm{C} \mathrm{NMR} \mathrm{(500} \mathrm{MHz,} \mathrm{CDCl3,} \mathrm{\delta ):} \mathrm{182.49,} \mathrm{159.25,} \mathrm{156.24,}$ $155.30,143.50,141.25,140.76,140.12,140.06,139.43,139.09,136.88,135.35,133.99,133.04$, $129.15,127.78,125.33,120.91,115.93,112.52,70.65,70.62,64.04,39.33,31.98,31.86,30.47$, 30.26 , 29.93, 29.49, 29.44, 29.32, 29.27, 29.23, 29.09, 29.04, 23.79, 23.07, 22.71, 22.66, 14.10, 11.10, 11.07. MS (MALDI-TOF) $m / z$ Calcd: 1915.0696, Found: 1915.1112.

3.1.4. Synthesis of $2,2^{\prime}-\left(\left(2 Z, 2^{\prime} Z\right)-(((4,4,9,9-T e t r a k i s(3-((2-e t h y l h e x y l) o x y) p h e n y l)-3,8-d i o c t y l-\right.$ 4,9-dihydro-s-indaceno[1,2-b:5,6- $\mathrm{b}^{\prime}$ ]dithiophene-2,7-diyl)bis(3-octyl-[2,2'-bithiophene]5',5-diyl))bis(methaneylylidene))bis(3-oxo-2,3-dihydro-1H-indene-2,1-diylidene)) dimalononitrile (IDT-BT-IC)

In a three-neck round bottom flask, to a stirring solution of compound $8(0.2 \mathrm{~g}$, $0.10 \mathrm{mmol})$ and 2-(3-oxo-2,3-dihydro- $1 \mathrm{H}$-inden-1-ylidene)malononitrile (0.1 g, $0.52 \mathrm{mmol})$ in dried $\mathrm{CHCl}_{3}(30 \mathrm{~mL})$, pyridine $(1 \mathrm{~mL})$ was added (Zhejiang Boom King Industrial Co., Ltd., Zhejiang, China). After the mixture was refluxed for $8 \mathrm{~h}$, water was poured and the mixture was extracted with $\mathrm{CHCl}_{3}$ and dried over $\mathrm{MgSO}_{4}$. After evaporating the solvent, the mixture was purified by silica gel column chromatography using methylene chloride:hexane ( $v: v=3: 1)$ as the eluent. Then, recrystallization from $\mathrm{CHCl}_{3}$ afforded IDTBT-IC as a black solid (0.15 g, 63.3\%). ${ }^{1} \mathrm{H}$ NMR (300 MHz, $\left.\mathrm{CD}_{2} \mathrm{Cl}_{2}, \delta\right): 8.82(\mathrm{~s}, 2 \mathrm{H}), 8.70-8.73$ $(\mathrm{q}, 2 \mathrm{H}), 7.94-7.96(\mathrm{~m}, 2 \mathrm{H}), 7.79-7.83(\mathrm{~m}, 4), 7.74(\mathrm{~s}, 2 \mathrm{H}), 7.52-7.53(\mathrm{~d}, J=4.04 \mathrm{~Hz}, 2 \mathrm{H}), 7.48(\mathrm{~s}$, $2 \mathrm{H}), 7.27-7.28(\mathrm{~d}, J=4.02 \mathrm{~Hz}, 2 \mathrm{H}), 7.20-7.22(\mathrm{t}, 4 \mathrm{H}), 6.99(\mathrm{~s}, 4 \mathrm{H}), 6.83-6.90(\mathrm{~m}, 8 \mathrm{H}), 3.81-3.83$ $(\mathrm{d}, J=5.91 \mathrm{~Hz}, 8 \mathrm{H}), 2.87-2.93(\mathrm{t}, 4 \mathrm{H}), 2.61-2.66(\mathrm{~m}, 4 \mathrm{H}), 1.68-1.80(\mathrm{~m}, 8 \mathrm{H}), 1.10-1.53(\mathrm{~m}$, $80 \mathrm{H}), 0.84-0.95(\mathrm{~m}, 36 \mathrm{H}), 0.69-0.73(\mathrm{~m}, 4 \mathrm{H}) .{ }^{13} \mathrm{C} \mathrm{NMR}\left(500 \mathrm{MHz}, \mathrm{CDCl}_{3}, \delta\right): 159.20,143.39$, $140.04,136.92,135.08,134.43,129.20,125.28,123.73,120.89$, 115.96, 112.53, 70.67, 70.64, 39.32, 
$31.98,31.86,30.46,30.00,29.63,29.44,29.36,29.31,29.24,29.09,29.05,23.78,23.06,22.72$, 22.66, 14.11, 11.11, 11.08. MS (MALDI-TOF) $\mathrm{m} / \mathrm{z}$ Calcd: 2267.1445, Found: 2268.5410.

3.1.5. Synthesis of $2,2^{\prime}-\left(\left(2 Z, 2^{\prime} Z\right)-((4,4,9,9\right.$-Tetrakis(3-((2-ethylhexyl)oxy)phenyl)-3,8dioctyl-4,9-dihydro-s-indaceno[1,2-b:5,6- $\left.\mathrm{b}^{\prime}\right]$ dithiophene-2,7-diyl)bis(3-octyl-[2,2' bithiophene]-5',5-diyl))bis(methaneylylidene))bis(5,6-difluoro-3-oxo-2,3-dihydro-1Hindene-2,1-diylidene)) dimalononitrile (IDT-BT-IC4F)

In a three-neck round bottom flask, pyridine $(1 \mathrm{~mL})$ was added to a stirring solution of compound 8 (0.3 g, $0.15 \mathrm{mmol})$ and 2-(5,6-difluoro-3-oxo-2,3-dihydro-1H-inden-1ylidene)malononitrile $(0.18 \mathrm{~g}, 0.78 \mathrm{mmol})$ in dried $\mathrm{CHCl}_{3}(30 \mathrm{~mL})$, and the mixture was refluxed for $8 \mathrm{~h}$. Water was poured, and the mixture was extracted with $\mathrm{CHCl}_{3}$ and dried over $\mathrm{MgSO}_{4}$. After evaporating the solvent, the mixture was purified by column chromatography using silica gel and methylene chloride:hexane $(v: v=3: 1)$ as the eluent. Then, the compound was recrystallized from $\mathrm{CHCl}_{3}$, affording IDT-BT-IC4F as a black solid (0.25 g, 68.2\%). ${ }^{1} \mathrm{H}$ NMR (300 MHz, $\left.\mathrm{CD}_{2} \mathrm{Cl}_{2}, \delta\right): 8.80$ (s 2H), 8.53-8.59 (q, 2H), $7.70-7.75$ (t, $4 \mathrm{H}), 7.53-7.55(\mathrm{~d}, J=4.06 \mathrm{~Hz}, 2 \mathrm{H}), 7.48(\mathrm{~s}, 2 \mathrm{H}), 7.28-7.29(\mathrm{~d}, \mathrm{~J}=4.05 \mathrm{~Hz}, 2 \mathrm{H}), 7.20-7.22(\mathrm{t}$, $4 \mathrm{H}), 7.00(\mathrm{~s}, 4 \mathrm{H}), 6.84-6.90(\mathrm{~m}, 8 \mathrm{H}), 3.81-3.83(\mathrm{~d}, J=5.89 \mathrm{~Hz}, 8 \mathrm{H}), 2.88-2.94(\mathrm{t}, 4 \mathrm{H}), 2.61-2.67$ (m, 4H), 1.68-1.80 (m, 8H), 1.09-1.54 (m, 80H), 0.85-0.95 (m, 36H), 0.70-0.72 (m, 4H). ${ }^{13} \mathrm{C}$ $\operatorname{NMR}\left(500 \mathrm{MHz}, \mathrm{C}_{2} \mathrm{D}_{2} \mathrm{Cl}_{4}, \delta\right): 185.69,159.48,158.70,156.65,155.98,149.94,148.52,134.37$, 141.73, 141.47, 141.41, 137.87, 137.44, 135.49, 134.38, 134.03, 133.27, 129.56, 129.35, 125.95, $121.65,121.07,116.24,116.16,114.51,114.32,113.23,71.27,69.70,64.35,39.49,32.00,31.92$, 30.70, 30.07, 30.01, 29.66, 29.54, 29.48, 29.38, 29.27, 29.22, 29.19, 29.05, 24.10, 23.12, 22.77, 22.72, 14.19, 11.25. MS (MALDI-TOF) $m$ / $z$ Calcd: 2339.1068, Found: 2339.1575.

3.1.6. Synthesis of 2,2'-((2Z,2'Z)-(((4,4,9,9-Tetrakis(3-((2-ethylhexyl)oxy)phenyl)-3,8-dioctyl4,9-dihydro-s-indaceno[1,2-b:5,6- $\mathrm{b}^{\prime}$ ]dithiophene-2,7-diyl)bis(3-octyl-[2,2'-bithiophene]5',5-diyl))bis(methaneylylidene))bis(5,6-dichloro-3-oxo-2,3-dihydro-1H-indene-2,1diylidene)) dimalononitrile (IDT-BT-IC4Cl)

In a three-neck round bottom flask, to a stirring solution of compound 8 (0.3 $\mathrm{g}$, $0.15 \mathrm{mmol})$ and 2-(5,6-dichloro-3-oxo-2,3-dihydro-1H-inden-1-ylidene)malononitrile (0.21 $\mathrm{g}, 0.78 \mathrm{mmol})$ in dried $\mathrm{CHCl}_{3}(30 \mathrm{~mL})$, pyridine $(1 \mathrm{~mL})$ was added at ambient temperature, and the mixture was refluxed for $8 \mathrm{~h}$. After water was poured, the mixture was extracted with $\mathrm{CHCl}_{3}$ and dried over $\mathrm{MgSO}_{4}$. After evaporating the solvent, the mixture was purified by silica gel column chromatography using methylene chloride:hexane $(v: v=3: 1)$ as the eluent. Then, the compound was purified by recrystallization from $\mathrm{CHCl}_{3}$, and IDT-BT-IC4Cl was obtained as a black solid (0.24 g, 63.7\%). ${ }^{1} \mathrm{H} \mathrm{NMR}\left(300 \mathrm{MHz}, \mathrm{CD}_{2} \mathrm{Cl}_{2}, \delta\right): 8.80(\mathrm{~s}, 2 \mathrm{H})$, $8.77(\mathrm{~s}, 2 \mathrm{H}), 8.00(\mathrm{~s}, 2 \mathrm{H}), 7.75(\mathrm{~s}, 2 \mathrm{H}), 7.60-7.62(\mathrm{~d}, J=4.04 \mathrm{~Hz}, 2 \mathrm{H}), 7.50(\mathrm{~s}, 2 \mathrm{H}), 7.28-7.30(\mathrm{~d}$, $J=3.98 \mathrm{~Hz}, 2 \mathrm{H}), 7.21-7.26(\mathrm{t}, 4 \mathrm{H}), 7.01(\mathrm{~s}, 4 \mathrm{H}), 6.86-6.89(\mathrm{~m}, 8 \mathrm{H}), 3.82-3.84(\mathrm{~d}, J=4.82 \mathrm{~Hz}$, $8 \mathrm{H}), 2.87-2.93(\mathrm{t}, 4 \mathrm{H}), 2.62-2.68(\mathrm{~m}, 4 \mathrm{H}), 1.72-1.79(\mathrm{~m}, 8 \mathrm{H}), 1.09-1.52(\mathrm{~m}, 80 \mathrm{H}), 0.87-0.97$ $(\mathrm{m}, 36 \mathrm{H}), 0.68-0.71(\mathrm{~m}, 4 \mathrm{H}) .{ }^{13} \mathrm{C}$ NMR $\left(500 \mathrm{MHz}, \mathrm{CDCl}_{3}, \delta\right): 185.81,159.48,158.60,156.66$, $156.01,150.45,148.72,146.65,143.35,141.93,141.53,139.69,139.52,138.79,138.00,137.93$, $136.24,135.50,134.61,133.28,129.68,129.35,126.93,125.98,125.34,121.59,121.14,121.05$, $116.24,114.51,114.40,113.23,71.24,69.72,64.34,39.50,31.99,31.91,30.71,30.04,29.66,29.47$, 29.38, 29.29, 29.26, 29.21, 24.10, 23.13, 22.76, 22.71, 14.18, 11.26. MS (MALDI-TOF) $\mathrm{m} / \mathrm{z}$ Calcd: 2402.9886, Found: 2407.0256.

\subsection{Fabrication of the OPV Devices}

The newly synthesized IDIC-based NFA was used to fabricate an inverted organic photovoltaic device, which was composed of indium thin oxide (ITO), ZnO, PBDB-T:NFA, $\mathrm{MoO}_{3}$, and $\mathrm{Ag}$ layers (Figure 3). ITO and Ag were used as cathode and anode, respectively, and $\mathrm{ZnO}$ and $\mathrm{MoO}_{3}$ were used as electron and hole extraction layers. In inverted structure organic photovoltaic cells, the $\mathrm{ZnO}$ and $\mathrm{MoO}_{3}$ are typically used as electron and hole transport layer respectively. This is because, the $\mathrm{ZnO}$ and $\mathrm{MoO}_{3}$ have appropriate $\mathrm{HOMO}$ and LUMO levels with PBDB-T:NFA and they are very stable in moisture and oxygen environments $[28,29]$. $\mathrm{ZnO}$ was synthesized via the sol-gel method, which affords inorganic 
oxide powders. The precursor solution for the sol-gel synthesis of $\mathrm{ZnO}$ consisted of a mixture of $0.315 \mathrm{~g}$ of zinc acetate dehydrate, $10 \mathrm{~mL}$ of 2-methoxyethanol, and $0.158 \mathrm{~mL}$ of ethanolamine (Sigma-Aldrich, St. Louis, MO, USA), which was stored at room temperature for $24 \mathrm{~h}$ without heat treatment. PBDB-T was widely used as the photoactive layer as a donor material with NFA-based acceptor materials such as ITIC and IDIC. There are many previous research about PBDB-T: IDIC and ITIC bulk hetero-junction OPVs system [30,31]. In our research, the PBDB-T was purchased from 1-Materials Company (Dorval, QC, Canada). The photoactive layer was prepared by adding PBDB-T:IDIC-based NFA in $1 \mathrm{~mL}$ of 1,2-chlorobenzene at a weight ratio of $1: 1$, followed by heating at $80^{\circ} \mathrm{C}$ for $10 \mathrm{~h}$ $\left(20 \mathrm{mg} / \mathrm{mL}\right.$ ). To fabricate the solar cell, an ITO substrate (device area: $0.0225 \mathrm{~cm}^{2}$ ) was washed with acetone and isopropyl alcohol (IPA) for $10 \mathrm{~min}$ using an ultrasonic cleaner and then dried $10{ }^{\circ} \mathrm{C}$ for $5 \mathrm{~h}$. After removing contaminants by ultrasonic cleaning, the substrate was made hydrophilic by UV-ozone treatment (UVC-30S) for $900 \mathrm{~s}$, which facilitated the coating by lowering the contact angle between the solution and the substrate during spin coating [32]. After that, the $\mathrm{ZnO}$ precursor solution was spin-coated at $3000 \mathrm{rpm}$ for $40 \mathrm{~s}$ at room temperature in an air atmosphere and then heated at $150{ }^{\circ} \mathrm{C}$ for $30 \mathrm{~min}$ to form a $\mathrm{ZnO}$ thin film $(40 \mathrm{~nm})$. Next, the PBDB-T:NFA active layer was spin-coated at $1000 \mathrm{rpm}$ for $60 \mathrm{~s}$ in a glove box filled with $\mathrm{N}_{2}$ gas and then heated at $150{ }^{\circ} \mathrm{C}$ for $15 \mathrm{~min}$ to form a thin film $(75 \mathrm{~nm})$. On the coated device, $10 \mathrm{~nm}$ of $\mathrm{MoO}_{3}$ as a hole extraction layer and $100 \mathrm{~nm}$ of $\mathrm{Ag}$ as an anode were stacked at a vacuum degree of $3 \times 10^{-6}$ using a thermal evaporator (SHIMADZU, Tokyo, Japan).

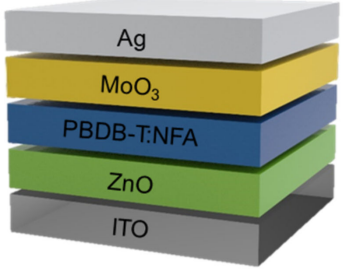

(a)

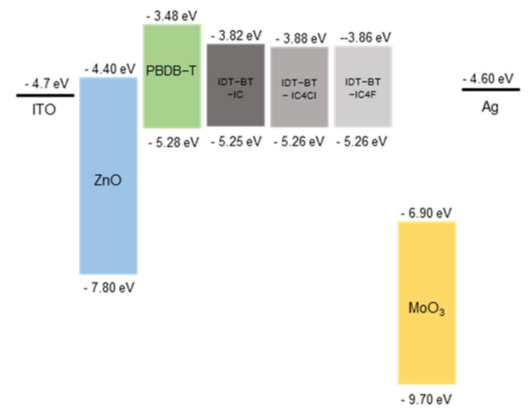

(b)

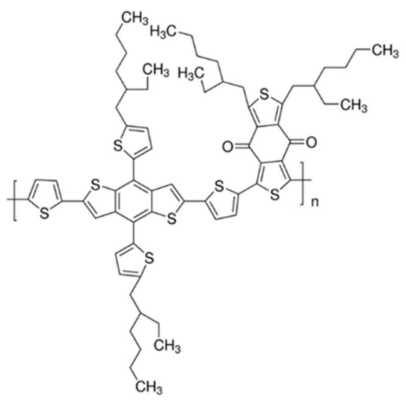

(c)

Figure 3. (a) Device structure and (b) energy band diagram of inverted organic photovoltaics. (c) molecular structures of PBDB-T.

To evaluate the performance of the OPVs, IV characteristics were measured using a solar simulator (Xe55) that emits light of AM 1.5G $\left(100 \mathrm{~mW} / \mathrm{cm}^{2}\right)$ and a Keithley 2400 source meter (Keithley Instruments, Solon, OH, USA), and EQE was measured with QuantX 300 (Newport Corporation, Irvine, CA, USA). Thin film analysis was performed to investigate the role of the NFA in the active layer. Absorption was taken with a UV-vis spectrophotometer (UV-2600i) (Light Machinery lnc, Ottawa, ON, Canada), and the roughness and shape of the surface were observed using an AFM (XE-100) (Park Systems, Suwon, Korea).

\section{Conclusions}

In summary, new bithiophene extended electron acceptors based on an $m$-alkoxyphenylsubstituted IDIC with three different end groups were developed, and their optical properties and thermal stability were analyzed. Then, inverted structure OPVs were fabricated using PBDB-T:IDIC-based NFAs and a BHJ system, and their characteristics were compared. The maximum absorption of NFAs was redshifted due to the presence of strong electronegative end groups. IDT-BT-IC, IDT-BT-IC4F, and IDT-BT-IC4Cl showed absorption maxima at 682,710 , and $726 \mathrm{~nm}$, respectively. In particular, the absorption of IDT-BT-IC was almost $50 \mathrm{~nm}$ redshifted compared with that of ITIC-OEh without the bithiophene unit. According to a thermal stability analysis, the new NFAs based on ID-BT showed crystalline properties. The OPV devices showed the highest efficiency (3.37\%) when IDT-BT-IC4F 
was used as an electron acceptor. The thin film of PBDB-T:IDT-BT-IC4F had a low average roughness of $0.263 \mathrm{~nm}$, which facilitates the extraction of electrons and holes. Furthermore, the absorption above $800 \mathrm{~nm}$ led to the generation of more excitons, and as a result, a high $\mathrm{J}_{\mathrm{sc}}$ of $8.31 \mathrm{~mA} / \mathrm{cm}^{2}$ and PCE of $3.37 \%$ were achieved.

Supplementary Materials: The following are available online; Optical and electrochemical properties of IDIC-based NFAs and more detailed synthesis (Figures S1-S28; Tables S1 and S2).

Author Contributions: Y.H.J. synthesis the IDIC-based NFAs and J.M.J. designed the OPV experiments and analyzed the data. Y.H.J., J.M.J., J.Y.K., Y.-H.K. wrote the paper; J.Y.K., Y.-H.K. reviewed and edited the paper. All authors have read and agreed to the published version of the manuscript.

Funding: This research was supported by National Research Foundation (NRF) funded by the Ministry of Science, ICT \& Future Planning (NRF 2016M1A2A2940911)). Also, this work was supported by the Technology Innovation Program (20015773) funded by the Ministry of Trade, Industry \& Energy (MOTIE, Korea) and GNU-Samsung Display center. The APC was funded by Gyeongsang National University.

Institutional Review Board Statement: Not applicable.

Informed Consent Statement: Not applicable.

Data Availability Statement: All the data associated with present manuscript have been included in Supplementary Materials.

Acknowledgments: Authors are thankful to GNU Graduate Innovation Program.

Conflicts of Interest: The authors declare no conflict of interest. The authors declare that they have no known competing financial interests or personal relationships that could have appeared to influence the work reported in this paper.

Sample Availability: Sample of the compounds are not available.

\section{References}

1. Zhang, J.; Tan, H.S.; Guo, X.; Facchetti, A.; Yan, H. Material insights and challenges for non-fullerene organic solar cells based on small molecular acceptors. Nat. Energy 2018, 3, 720-731. [CrossRef]

2. Zhang, G.; Zhao, J.; Chow, P.C.Y.; Jiang, K.; Zhang, J.; Zhu, Z.; Zhang, J.; Huang, F.; Yan, H. Non-fullerene Acceptor Molecules for Bulk Heterojunction Organic Solar Cells. Chem. Rev. 2018, 118, 3447-3507. [CrossRef]

3. Chen, W.; Zhang, Q.J. Mater Recent progress in non-fullerene small molecule acceptors in organic solar cells (OSCs). J. Mater. Chem. C 2017, 5, 1275-1302. [CrossRef]

4. Yan, C.; Abrlow, S.; Wang, Z.; Yan, H.; Jen, A.K.Y.; Marder, S.; Zhan, X. Non-fullerene acceptors for organic solar cells. Nat. Rev. Mater. 2018, 3, 18003. [CrossRef]

5. Lu, L.; Zheng, T.; Wu, Q.; Schneider, A.M.; Zhao, D.; Yu, L. Recent Advances in Bulk Heterojunction Polymer Solar Cells. Chem. Rev. 2015, 115, 12666-12731. [CrossRef]

6. Tang, A.; Zhan, C.; Yao, J. Series of Quinoidal Methyl-Dioxocyano-Pyridine Based $\pi$-Extended Narrow-Bandgap Oligomers for Solution-Processed Small-Molecule Organic Solar Cells. Chem. Mater. 2015, 27, 4719-4730. [CrossRef]

7. Cheng, Y.J.; Yang, S.H.; Hsu, C.S. Synthesis of Conjugated Polymers for Organic Solar Cell Applications. Chem. Rev. 2009, 109, 5868-5923. [CrossRef] [PubMed]

8. Zhou, H.; Yang, L.; You, W. Rational Design of High Performance Conjugated Polymers for Organic Solar Cells. Macromolecules 2012, 45, 607-632. [CrossRef]

9. Dominguez, I.F.; Distler, A.; Luer, L. Stability of Organic Solar Cells: The Influence of Nanostructured Carbon Materials. Adv. Energy Mater. 2017, 7, 1601320. [CrossRef]

10. Yunhao, C.; Yun, L.; Rui, W.; Hongbo, W.; Zhihao, C.; Jie, Z.; Zaifei, M.; Xiaotao, H.; Yong, Z.; Chunfeng, Z.; et al. A Well-Mixed Phase Formed by Two Compatible Non-Fullerene Acceptors Enables Ternary Organic Solar Cells with Efficiency over 18.6\%. Adv. Mater. 2021, 33, 2101733. [CrossRef]

11. Jianquan, Z.; Fujin, B.; Indunil, A.; Xiaoyun, X.; Siwei, L.; Chao, L.; Gaoda, C.; Han, Y.; Yuzhong, C.; Huawei, H.; et al. Alkyl-Chain Branching of Non-Fullerene Acceptors Flanking Conjugated Side Groups toward Highly Efficient Organic Solar Cells. Adv. Energy Mater. 2021, 11, 2102596. [CrossRef]

12. Chao, L.; Jiadong, Z.; Jiali, S.; Jinqiu, X.; Huotian, Z.; Xuning, Z.; Jing, G.; Lei, Z.; Donghui, W.; Guangchao, H.; et al. Non-fullerene acceptors with branched side chains and improved molecular packing to exceed $18 \%$ efficiency in organic solar cells. Nat. Energy 2021, 6, 605-613. [CrossRef] 
13. Park, S.Y.; Labanti, C.; Luke, J.; Chin, Y.C.; Kim, J.S. Organic Bilayer Photovoltaics for Efficient Indoor Light Harvesting. Adv. Energy Mater. 2021, 12, 2103237. [CrossRef]

14. Lin, Y.; Wang, J.; Zhang, Z.G.; Bai, H.; Li, Y.; Zhu, D.; Zhan, X. An Electron Acceptor Challenging Fullerenes for Efficient Polymer Solar Cells. Adv. Mater. 2015, 27, 1170-1174. [CrossRef] [PubMed]

15. Zhao, W.; Qian, D.; Zhang, S.; Li, S.; Inganäs, O.; Gao, F.; Hou, J. Fullerene-Free Polymer Solar Cells with over $11 \%$ Efficiency and Excellent Thermal Stability. Adv. Mater. 2016, 28, 4734-4739. [CrossRef]

16. Hou, J.; Inganas, O.; Friend, R.H.; Gao, F. Organic solar cells based on non-fullerene acceptors. Nat. Mater. 2018, 17, 119-128. [CrossRef]

17. Liu, Y.; Li, M.; Zhou, X.; Jia, Q.Q.; Feng, S.; Jiang, P.; Xu, X.; Ma, W.; Li, H.B.; Bo, Z. Non-fullerene Acceptors with Enhanced Solubility and Ordered Packing for High-Efficiency Polymer Solar Cells. ACS Energy Lett. 2018, 3, 1832-1839. [CrossRef]

18. Wadsworth, A.; Moser, M.; Marks, A.; Little, M.S.; Gasparini, N.; Brabec, C.J.; Baran, D.; McCulloch, I. Critical review of the molecular design progress in non-fullerene electron acceptors towards commercially viable organic solar cells. Chem. Soc. Rev. 2019, 48, 1596-1625. [CrossRef]

19. Bai, H.; Wang, Y.; Cheng, P.; Wang, J.; Wu, Y.; Hou, J.; Zhan, X.J. An electron acceptor based on indacenodithiophene and 1,1-dicyanomethylene-3-indanone for fullerene-free organic solar cells. Mater. Chem. A 2015, 3, 1910-1914. [CrossRef]

20. Bai, H.; Wang, Y.; Cheng, P.; Li, Y.; Zhu, D.; Zhan, X. Acceptor-Donor-Acceptor Small Molecules Based on Indacenodithiophene for Efficient Organic Solar Cell. ACS Appl. Mater. Interfaces 2014, 6, 8426-8433. [CrossRef]

21. Liu, W.; Xiang, X.; Yuan, J.; Leclerc, M.; Zou, Y.; Li, Y. Low-Bandgap Non-fullerene Acceptors Enabling High-Performance Organic Solar Cells. ACS Energy Lett. 2021, 6, 598-608. [CrossRef]

22. Seongyu, L.; Kwanghun, P.; Jonghoon, L.; Hyungcheol, B.; Minjae, S.; Jinho, L.; Jehan, K.; Heejoo, K.; Yunhi, K.; Soonki, K.; et al Achieving Thickness-Insensitive Morphology of the Photoactive Layer for Printable Organic Photovoltaic Cells via Side Chain Engineering in Non-fullerene Acceptors. Adv. Energy Mater. 2019, 9, 1900044. [CrossRef]

23. Jun, Y.; Tianyi, H.; Pei, C.; Yingping, Z.; Huotian, Z.; Jonathan Lee, Y.; Sheng-Yung, C.; Zhenzhen, Z.; Wenchao, H.; Rui, W.; et al Enabling low voltage losses and high photocurrent in fullerene-free organic photovoltaics. Nat. Commun. 2019, 10, 570. [CrossRef]

24. Barbato, M.; Meneghini, M.; Giliberto, V.; Giaffreda, D.; Magnone, P.; Derose, R.; Fiegna, C.; Meneghesso, G. Effect of shunt resistance on the performance of mc-Silicon solar cells: A combined electro-optical and thermal investigation. IEEE 2012, 38 , $1241-1245$.

25. Junyoung, K.; Swarup, B.; Yongju, L.; Hyeongwon, L.; Jaemin, J.; Hyeok, K. Highly Efficient Inverted Polymer Solar Cells Using an Indium Gallium Zinc Oxide Interfacial Layer. Sol. RRL 2020, 5, 2000673. [CrossRef]

26. An, Q.; Zhang, F.; Gao, W.; Sun, Q.; Zhang, M.; Yang, C.; Zhang, J. High-efficiency and air stable fullerene-free ternary organic solar cells. Nano Energy 2018, 45, 177-183. [CrossRef]

27. Ryu, H.S.; Lee, H.G.; Shin, S.C.; Park, J.; Kim, S.H.; Kim, E.J.; Shin, T.J.; Shim, J.W.; Kim, B.J.; Woo, H.Y. Terminal alkyl substitution in an A-D-A-type non-fullerene acceptor: Simultaneous improvements in the open-circuit voltage and short-circuit current for efficient indoor power generation. J. Mater. Chem. A 2020, 8, 23894-23905. [CrossRef]

28. Ioannis, I.; Isaac, S.; Giulia, L.; Thomas, M.B.; Franco, C. Inverted organic photovoltaics with a solution-processed ZnO/MgO electron transport bilayer. J. Mater. Chem. C 2021, 9, 3901-3910. [CrossRef]

29. Jiang, B.H.; Chan, P.H.; Su, Y.W.; Hsu, H.L.; Jeng, R.J.; Chen, C.P. Surface properties of buffer layers affect the performance of PM6:Y6-based organic photovoltaics. Org. Electron. 2020, 87, 105944. [CrossRef]

30. Li-Ming, W.; Qingduan, L.; Shengjian, L.; Zhixiong, C.; Yue-Peng, C.; Xuechen, J.; Haojie, L.; Weiguang, X.; Xiaozhi, Z.; Tao, Z. Quantitative Determination of the Vertical Segregation and Molecular Ordering of PBDB-T/ITIC Blend Films with Solvent Additives. ACS Appl. Mater. Interfaces 2020, 12, 24165-24173. [CrossRef]

31. Pei, C.; Rui, W.; Jingshuai, Z.; Wenchao, H.; Sheng-Yung, C.; Lei, M.; Pengyu, S.; Hao-Wen, C.; Meng, Q.; Chenhui, Z.; et al. Ternary System with Controlled Structure: A New Strategy toward Efficient Organic Photovoltaics. Adv. Mater. 2018, 30 , 1705243. [CrossRef]

32. Delplanque, A.; Henry, E.; Lautru, J.; Leh, H.; Buckle, M.; Nogues, C. UV/ozone surface treatment increases hydrophilicity and enhances functionality of SU-8 photoresist polymer. Appl. Surf. Sci. 2014, 314, 280-285. [CrossRef] 